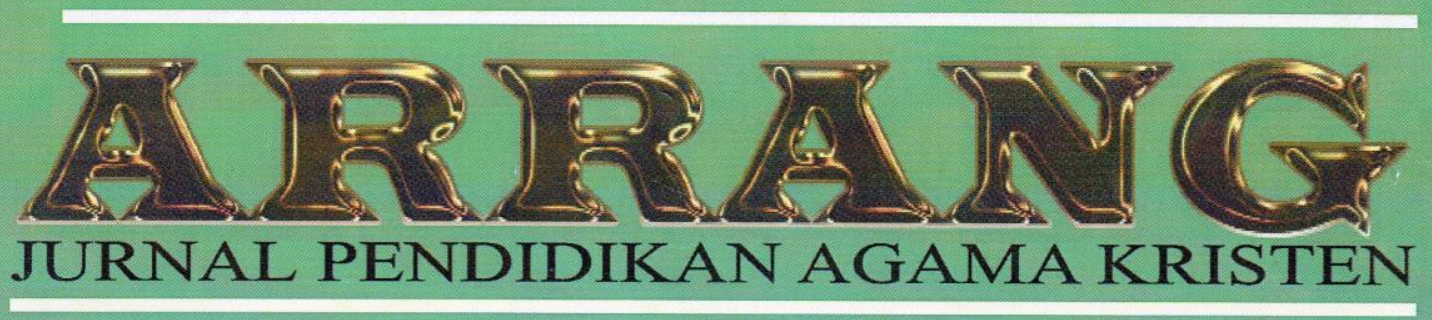

REVOLUSI MENTAL PENDIDIKAN KRISTEN

KAJIAN ETIS TENTANG PENDIDIKAN KRISTEN

DALAM MENCIPTAKAN AKHLAK MULIA

BAGI PENGEMBANGAN KARAKTER PESERTA DIDIK DI SEKOLAH

Maidiantius Tanyid

INTERNALISASI PAHAM ANTI KORUPSI DALAM DUNIA PENDIDIKAN Naomi Sampe

SIMBUANG KAYU:

EKSPRESI DAN REVITALISASI NILAI KETORAJAAN

Abraham Sere Tanggulungan

PENDIDIKAN KRISTEN DALAM KELUARGA

SEBAGAI UPAYA PENANGGULANGAN KEMEROSOTAN MORAL ANAK

Yonatan Sumarto

PERANAN GURU DALAM REVOLUSI MENTAL PENDIDIKAN

BAGI ANAK KORBAN PERCERAIAN

James Anderson Lola

GURU PENDIDIKAN AGAMA KRISTEN

SEBAGAI PELOPOR REVOLUSI MENTAL

Marsi Bombongan Rantesalu

MEMBUDAYAKAN MENTALITAS ILMIAH:

REVOLUSI MENTAL DALAM DUNIA PENDIDIKAN KRISTIANI di STAKN TORAJA

Yohanis Krismantyo Susanta

PAK DI ERA CYBERTECHNOLOGY

Rannu Sanderan

GURU:

AGEN PERUBAH MENTAL

Ismail Banne Ringgi'

TRANSFIGURASI PEMANGKU PENDIDIKAN YANG MEMBANGUN BERKESADARAN SECARA KONTEKSTUAL

Yanni Paembonan

SEKOLAH TINGGI AGAMA KRISTEN NEGERI TORAJA

Pusat Penelitian dan Pengabdian Masyarakat

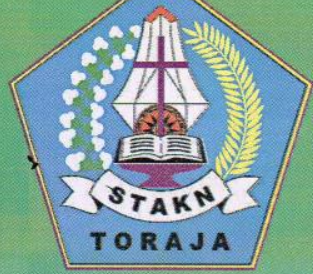


Jurnal “ARRANG”, Vol. IV, No. 1, 2017 / ISSN: 2442-3610

\title{
PENDIDIKAN KRISTEN DALAM KELUARGA SEBAGAI UPAYA PENANGGULANGAN KEMEROSOTAN MORAL ANAK Oleh: Yonatan Sumarto
}

\author{
Sekolah Tinggi Agama Kristen Negeri (STAKN) Toraja \\ Jl. Poros Makale-Makassar Km. 11,5 Mengkendek, Kabupaten Tana Toraja, \\ Sulawesi Selatan \\ Email; yonatansumarto@yahoo.co.id
}

\begin{abstract}
This paper discusses two subjects as scope: first, the scope of Christian education consisting of: the notion of Christian education, the importance of Christian education in the family, and the strategy of Christian education in the family. Second: the moral scope that includes: moral definition, moral values, moral decline of adolescents, and factors causing moral decline.

This paper aims to determine the factors that could be the cause of moral decline in adolescents and know the strategies that can be used in Christian education in the family as an effort to overcome the moral decline.

The conclusion of this paper is that moral decline is caused by many factors, among others: First, Lack of attention and religious education provided by parents to children. Second, the influence of the environment is not good. Third, the psychological pressure experienced by the child. Fourth, The influence of modern technology.
\end{abstract}

Keywords: Christian Education, Moral.

\section{PENDAHULUAN}

John W. Santrock dalam bukunya perkembangan remaja berkata bahwa, "Dewasa ini merupakan masa terbaik dan sekaligus terburuk bagi remaja masa kini. Dunia mereka memiliki kekuatan dan perspektif yang tidak pernah terimpikan 50 tahun yang lalu: computer, harapan hidup yang semakin panjang, seluruh planet dapat diakses melalui televisi, satelit, dan pesawat terbang. Namun, pengetahuan yang sedemikian banyak itu dapat membuat kekacauan dan bahaya. ${ }^{1}$

Pernyataan ini setidaknya menjadi sebuah awasan bagi para

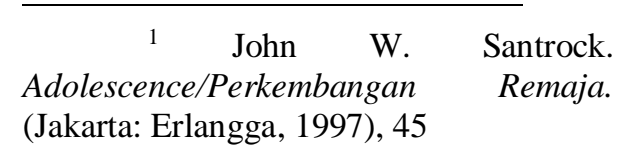


orang tua Kristen dalam memberikan didikan sedini mungkin untuk membentuk akhlak anak sesuai dengan nilai-nilai kristen.

Robert A. Schuller mengatakan bahwa masyarakat semakin lama semakin kehilangan sesuatu yang sangat penting yang disebut moralitas. ${ }^{2}$ Selanjutnya ia mengemukakan bahwa ketiadaan moralitas ini mengakibatkan kita harus membayar harga yang teramat mahal, seperti halnya rumah tangga yang hancur, orangorang yang patah semangat, hilangnya tujuan hidup, hilangnya harapan, hubungan yang rusak dan masyarakat yang hancur. ${ }^{3}$ Kemerosotan moral dipengaruhi oleh berbagai macam faktor. Salah satu faktor yang dikemukan oleh Robert A. Schuller adalah dunia perfilman, film dipenuhi dengan adegan seks, kekerasan, dan segala macam penyimpangan. ${ }^{4}$ Pernyataan ini diperkuat oleh Stephen Arterburn dan Jim Burns dalam bukunya "Arahkan dengan Jitu" dengan mengatakan bahwa ribuan sajian gambar amoral ditayangkan di bioskop, video, atau TV, dan sementara itu berbagai acara komedi mematikan kesadaran anak-anak untuk

2 Robert A. Schuller. Mencari Nilai-Nilai Moral. (Batam: Gospel Press, 2005), 7.

\footnotetext{
${ }^{3}$ Ibid., 7.

${ }^{4}$ Ibid,. 9.
}

menentukan hal yang benar dan salah. $^{5}$

Dengan berkembangnya ilmu pengetahuan dan teknologi tentunya memberikan kemudahankemudahan bagi manusia. Di satu sisi teknologi memberikan dampak yang positif, namun di lain sisi teknologi dapat memberikan dampak yang negatif. Dampak negatif akan mengacu pada hilangnya nilai-nilai moral pada diri manusia, yang akan mengakibatkan terjadinya bentukbentuk kejahatan. Kejahatan tidak lagi dianggap sebagai sesuatu yang bertentanggan dengan nilai-nilai agama ataupun nilai-nilai suatu budaya. Kejahatan yang dilakukan merupakan sebuah anggapan bahwa apa yang dilakukan adalah hal yang biasa. Hilangnya nilainilai moral pada diri seseorang berdampak pada sebuah prilaku yang tidak bermoral, prilaku ini merusak hakekatnya sebagai mahkluk yang diciptakan oleh Tuhan. Allah mengharapkan umat-Nya memiliki moral yang baik. Hakikat dari kepedulian Allah terhadap moral umat-Nya adalah pada hakikatnya Allah adalah Allah yang bermoral, sehingga sebuah perintah yang dikemukakan oleh Rasul Paulus

5 Stephen Arterburn dan Jim Burns, Arahkan dengan Jitu: Kiat Menanamkan Nilai-Nilai Kekristenan pada Remaja (Yogyakarta: ANDI, 2010), 3. 
dalam suratnya kepada jemaat di Roma dengan mengatakan bahwa, "Janganlah kamu menjadi serupa dengan dunia ini, tetapi berubahlah oleh pembaharuan budimu, sehingga kamu dapat membedakan manakah kehendak Allah: apa yang baik, yang berkenan kepada Allah dan yang sempurna (Roma 12:2). Kemerosotan moral menjadi sebuah masalah yang terjadi dalam sebuah tatanan dunia, bahkan menjadi sebuah masalah dalam ruang lingkup keluarga Kristen pada masa kini, kecemasan para orang tua terhadap anak-anak mereka menjadi sebuah bentuk reaksi mereka terhadap kemudahan-kemudahan yang dapat diakses oleh anak melalui berbagai sumber media masa yang bersifat negatif. Kerapuhan spiritual pada diri anak akan berdampak pada merosotnya moral pada diri anak tersebut.

W. Stanley Heath melihat bahwa zaman dimana manusia hidup saat ini timbul bermacammacam masalah, termasuk didalamnya adalah kenakalan remaja. Menurutnya masalah ini disebabkan oleh karena kegagalan dalam pendidikan anak, yaitu pembentukan kepribadian dan pola hidup yang seharusnya tuntas pada masa kecil. $^{6}$ Terhadap permasalahan ini Stanley

6 W. Stanley Heath, Teologi Pendidikan: Dasar Pelayanan Kepada Anak (Bandung: Kalam Hidup, 2005), 9. mengatakan bahwa, permasalahan ini terjadi akibat orang tua kurang membaca Firman Tuhan dan tidak mengerti bahwa mereka sendirilah yang bertanggung jawab untuk mendidik dan mengarahkan anak mereka. $^{7} \quad$ Pernyataan yang dikemukan oleh W. Stanley Heath bahwa keutuhan moral anak dipengaruhi oleh sejauhmana orang tua memahami perannya sebagai pendidik dalam sebuah keluarga, dengan demikian pernyataan ini akan menjadi sebuah asumsi bahwa moral anak akan menjadi baik atau sebaliknya menjadi tidak baik, sangat dipengaruhi oleh peran orang tua sebagai pendidik.

Pendidikan

Kristen merupakan mandat Alkitab, yang merupakan tanggung jawab dari keluarga, pendidikan harus dimulai dari keluarga. Dalam keluarga inilah peran orang tua sebagai pendidik perlu dimaksimalkan, orang tua bertanggung jawab dalam memberikan pendidikan agama Kristen kepada anakanaknya. Ketidakpedulian orang tua dalam memberikan pendidikan agama Kristen kepada anakanaknya, merupakan kegagalan terbesar bagi orang tua membangun karakter anak berdasarkan mandat Alkitab, Amsal 22:6 berkata didiklah orang muda menurut jalan yang patut baginya, maka pada masa tuannya

${ }^{7}$ Ibid,. 9. 
pun ia tidak akan menyimpang dari pada jalan itu.

Pentingnya pendidikan kristen dalam keluarga, karena pendidikan merupakan sarana untuk mendidik dan membimbing anak untuk mengetahui mana tindakan yang benar atau salah, mana pilihan yang benar atau salah. Salomo berkata bahwa, "Hai anakku, peliharalah perintah ayahmu, dan janganlah menyianyiakan ajaran ibumu. Tambatkalah senantiasa semuanya itu pada hatimu, kalungkanlah pada lehermu (Amsal 6:20,21). Dengan demikian betapa pentingnya pendidikan kristen yang harus diterapkan oleh orang tua selaku pihak yang bertanggung jawab dalam melaksanakannya.

\section{Kemerosotan}

moral tentunya merupakan sebuah pergumulan teologis, dimana adanya sebuah tuntutan Allah yang sempurna terhadap umat-Nya, tuntutan Allah terhadap umat-Nya adalah supaya umat-Nya menjaga kekudusan hidup, bukanlah sebuah tuntutan yang absurd, tetapi tuntutan ini dapat diwujudkan dalam kehidupan umat Tuhan sejauhmana setiap orang tua memahami dengan benar bahwa mereka adalah pendidik dalam keluarga yang dapat membangun sebuah keluarga yang hidup takut kepada Tuhan. Tidak ada jalan pintas bagi sebuah pembentukan moral yang utuh pada diri anak, dibutuhkan sebuah pemahaman yang benar dan tepat terhadap sebuah metode yang dapat diterapkan dalam keluarga sebagai upaya dari orang tua dalam menolong anak untuk membagun moral berdasarkan tuntutan Allah, sehingga perlu sekali untuk mengubah pola pikir para orang tua yang menitikberatkan gereja sebagai wadah bagi anak untuk menerima pendidikan Kristen, kepada suatu pemahaman bahwa pendidikan agama Kristen merupakan tanggung jawab daripada orang tua terhadap anakanaknya, yang seharusnya sudah diterapkan dalam keluarga.

\section{PEMBAHASAN}

Ruang Lingkup Pendidikan

$$
\text { Kristen }
$$

\section{Pengertian Pendidikan Kristen}

Robert W. Pazmino

"Pendidikan Kristen merupakan upaya ilahi dan manusiawi dilakukan secara bersahaja dan berkesinambungan, untuk memberikan pengetahuan, nilainilai, sikap-sikap, keterampilan, sensitivitas, tingkah laku yang konsisten dengan iman Kristen. Pendidikan mengupayakan perubahan, pembaharuan dan reformasi pribadi-pribadi, kelompok dan struktur oleh kuasa Roh Kudus, sehingga bersesuaian dengan kehendak Allah sebagaimana dinyatakan dalam Kitab Suci, terutama dalam Yesus 
Kristus, serta diwujudkan dalam upaya itu. $^{8}$

B. S. Sidjabat dalam menanggapi pengertian yang dikemukakan oleh Robert W. Pazmino mengatakan bahwa definisi di atas berbunyi begitu umum, dan dapat diimplikasikan ke dalam berbagai konteks pendidikan, yakni di dalam rumah tangga, di sekolah, di gereja dan di tengah-tengah

masyarakat.

Pendidikan selalu merupakan usaha yang bersahaja dan sadar tujuan, memiliki standar otoritas, memakai manusia sebagai media (alat), memiliki bahan (content) yang bersesuaian dengan tujuan, serta membutuhkan penjelasan waktu. Di samping itu, pendidikan Kristen tidak saja berupaya mengalihkan nilai-nilai dasar, doktrin atau ajaran; ia juga berusaha mengalihkan perlengkapan-perlengkapan yang sangat dibutuhkan oleh konteks di mana anak didik berada. Individuindividu diperlengkapi sedemikian rupa, sehingga dalam bimbingan Allah mampu menjadi saluran berkat bagi orang lain, dalam rangka pembaharuan keluarga, gereja dan masyarakatnya ${ }^{9}$

Kepentingan Pendidikan Kristen Dalam Keluarga

8 B. Samuel Sidjabat, Strategi Pendidikan Kristen: Suatu Tinjauan Teologis-Filosofis (Yogyakarta: Yayasan ANDI, 1999), 10.

${ }^{9}$ Ibid,. 106,107.
Dalam Perjanjian Lama ditegaskan bahwa tanggung jawab orang tua adalah mendidik anakanaknya dengan tekun. Tanggung jawab orang tua dalam mendidik anak-anaknya termaktub dalam Ulangan 6:6-7 yang berbunyi: "Apa yang Kuperintahkan kepadamu pada hari ini haruslah engkau perhatikan, haruslah engkau mengajarkannya berulangulang kepada anak-anakmu dan membicarakannya apabila engkau duduk di rumahmu, apabila engkau sedang dalam perjalanan, apabila engkau berbaring dan apabila engkau bangun. Manfaat yang akan dicapai bilamana perintah tersebut diaplikasikan adalah anakanak akan mengasihi Allah.

\section{Mendidik Anak Hidup Takut Akan Tuhan}

Manfaat dari pendidikan Kristen dalam keluarga adalah supaya anak hidup takut akan Allah. Hidup takut akan Allah tersirat dalam Ulangan 6:2, berbunyi: supaya seumur hidupmu engkau dan anak cucumu takut akan TUHAN, Allahmu, dan berpegang pada segala ketetapan dan perintah-Nya yang kusampaikan kepadamu, dan supaya lanjut umurmu. Ulangan 6:13 berbunyi: engkau harus takut akan TUHAN, Allahmu; kepada Dia haruslah engkau beribadah dan demi nama-Nya engakau harus bersumpah. Ulangan 10:12 berbunyi: "maka sekarang, hai orang Israel, apakah yang 
dimintakan padamu dari TUHAN, Allahmu, selain dari takut akan TUHAN Allahmu, hidup menurut segala jalan yang ditunjukannya, mengasihi Dia, beribadah kepada TUHAN, Allahmu, dengan segenap hatimu dan dengan segenap jiwamu. Yosua 24:14 berbunyi: oleh sebab itu, takutlah akan TUHAN dan beribadahlah kepada-Nya dengan tulus ikhlas dan setia.

Menurut William Dyrness, ketakutan Israel akan Tuhan adalah kesadaran yang penuh kekaguman bahwa Allah yang kudus telah berkenan menoleh kepada mereka serta memilih mereka menjadi umat-Nya. Oleh karena itulah mereka harus hidup dalam rasa takut, namun ketakutan yang menuntut kepada keyakinan dan kepercayaan, dan bukan kepada ketidakpastian yang mematahkan semangat. ${ }^{10}$

Tentunya takut akan Tuhan merupakan pokok penting yang harus diketahui oleh anak, dan dalam hal ini orang tua mempunyai tanggung jawab dalam memberikan didikan tersebut, sehingga yang tentunya diharapkan adalah kehidupan anak di hadapan Allah adalah hidup yang takut kepada Tuhan. Hidup yang takut kepada Tuhan dibangun dalam berbagai dimensi, misalnya anak

10 William Dyrness, Tema-Tema Dalam Teologi Perjanjian Lama (Malang: Gandum Mas,1979),142. yang hidup takut kepada Tuhan adalah anak yang membangun sebuah hubungan dengan Tuhan. Hubungan tersebut didasarkan pada pengenalan anak kepada Allah. Anak yang hidup takut akan Tuhan akam mampu membedakan perbuatan-perbuatan yang baik dan buruk, anak yang hidup takut akan Tuhan tentunya akan memilih untuk melakukan perbuatanperbuatan yang baik.

\section{Menanamkan Nilai-Nilai Rohani Pada Anak}

James Dobson mengatakan, "kontribusi paling berharga yang dapat diberilkan orangtua kepada anaknya adalah menanamkan iman sejati pada Allah dalam dirinya. ${ }^{11}$

Menurut Nicholas P. Wolterstorff, sasaran tertinggi pendidikan, dalam pandangan Kristen, bukanlah pendewasaan murid, meskipun pendewasaan memang akan terjadi. Bukan sosialisasi murid, meskipun sosialisasi juga akan terjadi. Sasarannya adalah membimbing anak ke dalam kehidupan yang memelihara iman kepada Allah yang kita ingat dan harapkan. ${ }^{12}$

11 Stephen Arterburn \& Jim Burns, Arahkan Dengan Jitu: Kiat-Kiat Menanamkan Nilai-Nilai Kekristenan Pada Remaja (Yogyakarta: ANDI, 2010), 253.

12 Nicholas P. Wolterstorff, Mendidik Untuk Kehidupan: Refleksi Mengenai Pengajaran dan Pembelajaran Kristen (Surabaya: Momentum, 2007), 121. 
Pendidikan Kristen dalam keluarga bermanfaat untuk menanamkan nilai-nilai rohani pada diri anak. Salah satu nilai rohani yang mendasar adalah iman. Pelaksanaan pendidikan Kristen dalam keluarga diharapkan akan menghasilkan anak yang memiliki iman yang benar. Iman tidak sendirinya dimiliki oleh seorang anak, tanpa ada suatu pengetahuan tentang dasar iman itu sendiri. Rasul Paulus menulis dalam surat Roma tentang bagaimana seseorang memiliki iman dengan mengatakan bahwa, iman timbul dari pendengaran, dan pendengaran oleh firman Kristus (Roma 10:17), dengan demikian tugas orangtua adalah memperdengarkan firman Tuhan kepada anaknya.

Tahun $1536 \quad$ Calvin menetapkan bahwa muda-mudi gereja wajib dididik dalam ajaran Kristen yang murni. Dengan demikian mereka belajar bertanggung jawab secara pribadi dalam hal-hal iman, dan umat Tuhan mantap bertumbuh dalam ajaran yang sama. Pengajaran seperti ini wajib diteruskan oleh orang tua kepada anak-anaknya, sehingga setiap orang mendapat ajaran Kristen yang murni. ${ }^{13}$ Jadi sangat penting bagi orang tua untuk memberikan pendidikan

13 G. Riemer, Ajarlah Mereka (Jakarta: Yayasan Komunikasi Bina Kasih/OMF, 2006), 94.
Kristen bagi anak-anak mereka, hal ini bermanfaat untuk membangun iman anak.

\section{Mendidik Anak Menjadi Dewasa Secara Rohani}

Kedewasaan merupakan proses pergumulan dan tercapainya kemenangan di dalam menghadapi berbagai tantangan. Namun, kemenangan itu tidak pernah statis. Sebab itulah, pendidikan Kristen hadir untuk membimbing dan memberi perlengkapan bagi individu dan kelompok guna mencapai kedewasaannya. Bagaimana mereka menang dan menghadapi perjuangan hidup. karena kedewasaan berjalan sebagai proses di dalam konteks ruang dan waktu, maka pendidikan Kristen tak henti-hentinya memberikan bimbingan itu. Sebab dalam perspektif Kristen, kedewasaan merupakan proses perubahan hidup dari satu tahap ke tahap berikutnya, oleh dinamika Roh Kudus, ke arah pengenalan yang lebih dekat dengan Allah melalui Yesus Kristus. ${ }^{14}$

Sasaran dari pendidikan Kristen dalam keluarga yang diperuntukan bagi anak adalah pertumbuhan menuju kedewasaan iman di dalam Yesus Kristus. Kedewasaan dalam Kristus ini sangat mendalam di jelaskan oleh

14 B. Samuel Sidjabat, Strategi Pendidikan Kristen: Suatu Tinjauan Teologis-Filosofis (Yogyakarta: Yayasan ANDI, 1999), 16. 
kitab Efesus itu sendiri. Pertama, kedewasaan itu adalah sebagai pertumbuhan atau proses perubahan hidup oleh kuasa Roh Allah dan pengajaran firman-Nya. Kedua, kedewasaan itu meliputi aspek kognitif atau pengenalan, pengertian, pemahaman akan Yesus Kristus, dalam artian secara pribadi. Iman yang bertumbuh kearah kedewasaan akan semakin memahami betapa besar kasih Allah bagi manusia yang telah dinyatakan melalui Yesus Kristus. ${ }^{15}$ Pelaksanaan pendidikan Kristen bagi anak diharapkan menghasilkan kedewasaan pada diri anak. Kedewasaan yang dimaksud adalah anak memiliki kerohanian yang dewasa, hal ini terindikasi pada pertumbuhan iman.

\section{Membentuk Karakter Anak}

Bagi orang tua kristen, hasil dari pendidikan adalah bahwa anak-anak kita menaruh hormat kepada Allah, kepada kita sebagai orang tua, kepada gereja, dan kepada negara. ${ }^{16}$ Dengan demikian, orang tua perlu menyadari bahwa tanpa adanya sebuah penerapan pendidikan Kristen bagi anak, maka karakter anak akan menjadi anak yang bermasalah.

15 Ibid,. 43.

16 William \& Candera Backus, Menjadi Orang Tua Yang Berwibawa (Jakarta: YPII, 1995), 210.

\section{Strategi Pendidikan Kristen} dalam Keluarga

Yang dimaksudkan dengan strategi pendidikan kristen dalam keluarga adalah suatu rencana yang cermat mengenai kegiatan untuk mencapai sasaran khusus. Dalam hal ini adalah pencapaian terhadapa moral atau akhlak yang yang baik. Adapun strategi-strategi yang dimaksud adalah sebagai berikut:

\section{Penerapan Disiplin}

Siapa tidak menggunakan tongkat, benci kepada anaknya, tetapi siapa mengasihi anaknya, menghajar dia pada waktunya (Amsal 13:24). Setidaknya perkataan hikmat ini menjadi dasar dari pemberian disiplin kepada anak. Orang tua dapat menggunakan bentuk ini dalam memberikan pendidikan kristen bagi anak-anaknya.

Menrurut Roy Lessin, disiplin mengalir dari kasih. Kasih menginginkan yang terbaik untuk seseorang. Disiplin adalah bagian dari kasih. Karena saya menginginkan yang terbaik untukmu, saya tidak akan membiarkanmu berbuat atau menjadi sesuatu yang akan menyebabkan engkau kehilangan hal yang terbaik itu. ${ }^{17}$

\begin{tabular}{c}
$\begin{array}{r}\text { Roy } \\
\text { Lissien } \\
\text { alasan } \\
\text { mendisiplinkan anak-anak, yaitu: }\end{array}$ \\
\hline${ }^{17}$ Roy Lessin, Disiplin Keluarga \\
(Malang: Gandum Mas, 1978), 77.
\end{tabular}


Pertama, karena mereka membutuhkannya, Amsal 22:15 berbunyi: kebodohan melekat pada hati orang muda, tetapi tongkat didikan akan mengusir dari padanya. Tidak seorangpun dilahirkan dalam keadaan sempurna. Disiplin termasuk cara Allah untuk membawa seseorang sedini mungkin kepada Dia dan menyesuaikan hidup itu dengan citranya; Kedua, karena Allah menyuruh orang tua mendisiplin anak-anak. Allah sebagai Bapa surgawi kita, juga mendisiplin anak-anak rohani-Nya. ${ }^{18}$ Ibrani 12:6 yang berbunyi: karena Tuhan menghajar orang yang dikasihiNya, dan Ia menyesah orang yang dikasihi-Nya sebagai anak.

Baik anak-anak maupun orang tua harus mengerti bahwa Allah memerintahkan ibu bapak untuk mendisiplin anak-anak. Apabila anak-anak mengetahui bahwa orang tua mendisiplin mereka berdasarkan perintah Allah, maka mereka tidak akan merasa benci, tetapi justru akan menghormati dan mengagumi orang tua mereka. Pada waktu anak-anak bertambah besar, mereka menyadari bahwa disiplin yang mereka alami adalah suatu tindakan ketaatan kepada Allah dari orang tua yang sungguh mengasihi mereka. ${ }^{19}$

\footnotetext{
18 Ibid,. 78.

${ }^{19}$ Ibid,. 79.
}

Billy Graham mengatakan bahwa, di tengah keluarga harus ada disiplin. ${ }^{20}$ Alkitab mengatakan: "Hajarlah anakmu selama ada harapan, tetapi jangan engkau menginginkan kematiannya" (Amsal 19:18). "Jangan menolak didikan dari anakmu ia tidak akan mati kalau engkau memukulnya dengan rotan (Amsal 23:13). Alkitab mengatakan bahwa kita harus memelihara anak-anak kita agar mereka takut akan Tuhan, dan dengan pengajaran dan nasehat Tuhan.

Jarot Wijanarko megatakan pendisiplinan adalah bagian dari pendidikan. Tidak menghukum anak, berarti tidak sedang mendidik, bahkan Firman Tuhan mengatakan tidak mengasihi anak. Bagian dari mendidik adalah menghukum dan mendisiplin anak, itu satu bentuk dari kasi dan perhatian. $^{21}$ Tujuan dan fungsi hukuman adalah untuk menekankan dan menegakkan peraturan secara lebih sungguhsungguh. Fungsi hukuman adalah untuk menegaskan peraturan, untuk menyatakan kesalahan, untuk menyadarkan seseorang yang berada di jalan yang salah dan meninggalkan jalan tersebut.

${ }^{20}$ Billy Graham, Keluarga Yang Berpusatkan Kristus (Bandung: Kalam hidup, 1997), 38

21 Jarot Wijanarko, Mendidik Anak: Nilai Hidup, Integritas, Karakter (Jakarta: Suara Pemulihan, 2008), 10. 
Hukuman juga berguna untuk seseorang belajar untuk mau diatur. ${ }^{22}$

\section{Pemberian Teladan}

Paulus menulis kepada Timotius: "Jadilah teladan bagi orang-orang percaya, dalam perkataanmu, dalam tingkah lakumu, dalam kasihmu, dalam kesetiaanmu, dan dalam kesucianmu (I Timotius 4:12). Dari pernyataan ini Billy Graham menyatakan bahwa, hal ini berlaku juga bagi saudara sebagai ayah dan kepala keluarga. ${ }^{23}$ Selanjutnya Billy Graham mengatakan bahwa: Saya ingin menjadi teladan di tengah keluarga saya. Saya menghendaki agar keluarga saya melihat Kristus di dalam diri saya. Kalau saudara tidak mau hidup salah, kalau saudara tidak mau takut akan Allah demi kebaikan anak-anak saudara. Biarlah mereka melihat seorang ayah yang saleh. Biarlah mereka melihat seorang ibu yang saleh ${ }^{24}$ Ada pepatah yang mengatakan bahwa lebih baik satu perbuatan dari pada seribu perkataan. Anak lebih banyak mencontoh dari pada mendengar, sehingga sebagai orang tua perlu memberikan teladan hidup bagi anak. Dalam hal ini orang tua harus memberikan teladan kepada

\footnotetext{
${ }^{22}$ Ibid,. 12.

${ }^{23}$ Billy Graham, Keluarga Yang Berpusatkan Kristus (Bandung: Kalam Hidup, 1997), 36.

${ }^{24}$ Ibid,. 36.
}

anak melalui perbuatan dan perkataan yang pantas/sopan. Dengan demikian keteladanan merupakan salah satu faktor yang dapat membentuk moral anak menjdi anak yang bermoral.

\section{Peran Orang Tua Terhadap Anak}

yang

Orang tua sebagai pihak

bertanggungjawab terhadap

pemenuhan seluruh kebutuhan anak, termasuk pemenuhan kebutuhan rohani perlu mengetahui beberapa peran penting yang harus dimainkan. Berikut ini akan diuraikan beberapa peran yang perlu dimainkan oleh orang tua.

\section{Peranannya Sebagai Pendidik}

Peran sebagai pendidik menentukan kualitas hidup anak, yang menyangkut sebuah keutuhan hidup dari anak. Manakala peran ini tidak terlaksana maka dampak yang dihasilkan adalah hilangnya kualitas hidup anak yang ditandai dengan hilangnya nilai-nilai kekristenan pada diri anak. Menurut Jarot Wijanarto, dunia semakin tidak ramah, lingkungan semakin membuat orang kuatir, narkoba, pornografi begitu dekat dengan anak-anak. ${ }^{25}$ Ini adalah sebuah fakta yang terjadi dalam lingkungan dimana anak berada, sehingga untuk mencegah agar

25 Jarot Wijanarko, Anak Berakhlak: Kecerdasan Spiritual (Tangerang: Happy Holy Kids, 2007), 40. 
anak tidak terlibat dalam hal-hal yang merusak moralnya, maka Jarot Wijanarto berpendapat bahwa inilah saatnya bagi orang tua untuk menanamkan ke dalam diri anak nilai hidup untuk membentuk karakter sehingga anak memiliki integritas yang utuh. ${ }^{26}$ Sebagai pendidik, orang tua perlu memiliki wawasan yang luas terhadap nilai-nilai hidup yang akan diajarkan kepada anakanaknya, nilai-nilai yang dimaksudkan adalah Firman Tuhan. Pemazmur mengemukakan bahwa, "dengan apakah seorang muda mempertahankan kelakuannya bersih? Dengan menjaganya sesuai dengan FirmanMu (Mazmur 119:9). Sebagai pendidik, orang tua tentunya harus memahami bahwa kebenaran Allah merupakan ukuran untuk menentukan sebuah prilaku, apakah prilaku itu benar dan dapat diterima ataukah prilaku tersebut bertentangan dengan Firman Allah. Prilaku atau perbuatan anak yang baik maupun yang tidak baik tidak dapat ditentukan oleh sebuah nilai kebudayaan yang berlaku dalam sebuah masyarakat, atapun tidak ditentukan oleh teori-teori yang dikembangkan oleh pikiran manusia.

Peran orang tua sebagai pendidik dipertegas di dalam Kitab Ulangan 6:7, kata yang digunakan sehubungan dengan pendidik

${ }^{26}$ Ibid,. 40. adalah kata mengajar. Tugas seorang pendidik adalah memberikan pengajaran kepada anak, sehingga anak memiliki sebuah pengetahuan tentang pokok-pokok yang diajarkan kepadanya. Mengajar merupakan sebuah landasan untuk menanamkan nilai-nilai rohani pada diri anak. Mengajar berarti suatu usaha untuk menyampaikan sebuah pesan yang terkandung dalam sebuah ajaran yang memiliki nilai-nilai rohani yang dapat membangun dan membentuk akhlak anak didik. Penerapan proses mengajar oleh pendidik dalam hal ini orang tua kepada anak didik tentunya memiliki tujuan yang hendak dicapai, yaitu terbentuknya moral pada diri anak. Perlu pula bagi orang tua untuk membuat semacam kurikulum pengajaran berdasarkan pokokpokok iman Kristen, hal ini tentunya memberikan kemudahan bagi orang tua dalam memberikan pengajaran yang Alkitabiah, sehingga pada akhirnya pengetahuan anak tentang kebenaran Allah dapat terbentuk dalam pola pikirnya.

Kepedulian orang tua terhadap kebutuhan rohani anak merupakan hal yang mendasar dalam membangun wawasan anak terhadap berbagai pengetahuan tentang teologi. Tanpa adanya suatu upaya yang dilakukan oleh orang tua dalam usaha pemenuhan kebutuhan anak dalam segi rohani, 
maka yang akan dihasilkan adalah ketidaktahuan anak terhadap nilainilai rohani yang akan berdampak pada sebuah pembentukan karakter yang menyimpang dari asas-asas ajaran Kristen. Anak yang sama sekali tidak pernah mendapat didikan secara rohani besar kemungkinan akan terpengaruh dengan pandangan-pandangan sekuler yang pada akhirnya ia akan membangun sebuah pola pikir yang tidak sejalan dengan kebenaran Allah. Anak tidak akan peduli terhadap dosa, perbuatan dosa dianggap sebagai hal yang tidak bertentangan, bahkan bagi anak prilaku ini merupakan sebuah gaya hidup.

\section{Peranannya Sebagai Konselor}

Bila semua orang tua memahami bahwa dirinya adalah seorang konselor, maka tidak sulit bagi anak untuk mendapatkan konseling. Konseling bagi anak sangat perlu, dengan sebuah asumsi bahwa anak-anak diperhadapkan dengan masalah yang sangat kompleks, sehingga anak membutuhkan bimbingan dari orang tua sebagai pihak yang bertanggung jawab untuk menolongnya.

Menurut kamus besar bahasa Indonesia konselor adalah orang yang melayani konseling; penasehat; penyuluh. ${ }^{27}$ Konseling adalah pemberian bimbingan oleh

27 Kamus Besar Bahasa Indonesia (Jakarta: Balai Pustaka, 2001). yang ahli kepada seseorang; pengarahan. Sedangkan konseli adalah orang yang membutuhkan nasihat (arahan). Dalam konteks keluarga, orang tua berperan sebagai konselor dalam memberikan bimbingan kepada anak (konseli). Menurut Robert Smith, pelayanan pertama seorang konselor diberikan kepada pasangannya dan keluarganya. ${ }^{28}$ Pandangannya tersebut dikemukakan sebagai sebuah asumsi bahwa kita tidak dapat menolong orang tua lain beserta anak-anak mereka, apabila kita sendiri tidak menggunakan waktu secara tepat untuk melatih serta mendisiplinkan anak-anak kita sendiri. Kita harus membesarkan mereka dengan ajaran dan pendidikan. ${ }^{29}$ Pelayanan konseling dimulai dalam sebuah ruang lingkup kecil yaitu keluarga, karena pada dasarnya setiap anak berada dalam sebuah masalah, hal ini perlu diketahui oleh seorang konselor. Ada orang tua tidak menyadari bahwa dirinya adalah seorang konselor, ketidaktahuan ini didasarkan pada sebuah pengetahuan bahwa anak-anaknya tidak selalu dalam masalah. Sehingga akan menimbulkan sikap acuh tak acuh terhadap permasalahan yang sedang dihadapi oleh anaknya. 
Penting bagi seorang konselor untuk mengetahui tahaptahap dalam memberikan konseling kepada konseli. Milton Mayeroff berpendapat bahwa seorang konselor harus memberikan perhatiannya kepada konseli, karena memperhatikan berarti menolong orang lain berkembang. ${ }^{30}$ Melihat pada apa yang dikemukan oleh Mayeroff tentang unsur-unsur penting yang harus diperhatikan oleh seorang konselor, yang walaupun dalam penjabarannya tidak menyentuh kebutuhan rohani seorang anak, namun unsur-unsur tersebut dapat diaplikasikan dalam sebuah proses konseling. Unsur-unsur yang dimakaksud adalah memperhatikan, kesetiaan untuk memperhataikan, kesabaran untuk memperhatikan, semuanya ini dilakukan demi menolong anak yang bermasalah. Sangat penting bagi seorang konselor untuk memiliki sebuah tujuan dalam memberikan konseling adalah memberikan pertolongan bagi konseli, bukan mencari-cari kesalahan untuk memberikan hukuman. Prinsipnya adalah menolong. Pada hakikatnya bahwa orang tua sebagai konselor berperan dalam memberikan nasihat kepada anak, nasihat didasarkan pada Firman Allah

30 Milton Mayeroff, Seni Memperhatikan (Jakarta: Gramedia Pustaka Kita, 1991), 27. sebagai standar tertinggi dalam menolong anak guna memberikan pengertian tentang tuntutan Allah yang harus dipatuhi. Anak yang mendapat nasihat berupa ajaran Firman Allah, akan dapat mengambil sebuah keputusan yang tepat bilamana ia diperhadapkan dengan suatu pilihan yang berhubungan dengan keputusan moral. Orang tua sebagai konselor Kristen harus mampu mengevaluasi dan mengintrospeksi dirinya, sejauhmana ia memiliki ciri-ciri yang sejati sebagai seorang konselor Kristen. Dengan demikian maka tugas sebagai seorang konselor dapat dilaksanakn guna memberikan mimbingan dan arahan kepada anak.

\section{Ruang Lingkup Moral Menurut Singgih}

D. Gunarsa, pada hakekatnya, para orang tua mempunyai harapan agar anak-anak mereka tumbuh dan berkembang menjadi anak yang baik, tahu membedakan apa yang baik dan yang tidak baik, tidak mudah terjerumus dalam perbuatan-perbuatan yang dapat merugikan dirinya sendiri maupun merugikan orang lain. Harapanharapan ini kiranya akan mudah terwujud apabila sejak semula, orang tua telah menyadari akan peranan mereka sebagai orang tua yang besar pengaruhnya terhadap 
perkembangan moral anak. ${ }^{31}$ Menurut Moh. Shochib, perlu adanya kontrol orang tua terhadap prilaku anak. Prilaku anak yang memperoleh prioritas kontrol orang tua adalah prilaku-prilaku dalam merealisasikan nilai moral dasar. ${ }^{32}$

\section{Defenisi Moral}

Istilah moral berasal dari kata Latin: Mos (Moris) yang berarti adat istiadat, kebiasaan, tata cara kehidupan. Sedangkan pengertian moralitas berhubungan dengan keadaan nilai-nilai moral yang berlaku dalam suatu kelompok sosial atau masyarakat. ${ }^{33}$ Kamus besar bahasa Indonesia memberikan beberapa defenisi terhadap kata moral, yaitu moral diartikan sebagai ajaran tentang baik buruk yang diterima umum mengenai perbuatan, sikap, kewajiban; akhlak; budi pekerti; susila, sedangkan moralitas mengandung pengertian sopan santun, segala sesuatu yang berhubungan dengan etiket atau adat sopan santun. ${ }^{34}$ Moralitas artinya keadaan nilai-nilai moral

31 Singgih D. Gunarsa \& Yulia Singgih D. Gunarsa, Psikologi Perkembangan Anak dan Remaja (Jakarta: BPK Gunung Mulia, 2008), 60.

32 Moh. Shochib, Pola Asuh

Orang Tua Dalam Membantu Anak Mengembangkan Disiplin Diri (Jakartra: PT Rineka Cipta, 1998),

${ }^{33}$ Ibid,. 61.

34 Kamus Besar Bahasa Indonesia (Jakarta: Balai Pustaka, 2001), 755. dalam hubungan dengan kelompok sosial. Tingkah-laku yang bermoral artinya tingkah-laku yang sesuai dengan nilai tata cara/adat yang dalam sesuatu kelompok. Moralitas adalah sesuatu yang dipelajari. Tidak ada anak yang memperkembangkan nilai-nilai moral oleh diri dirinya sendiri. Nilai-nilai moral bukanlah sesuatu yang diperoleh dari kelahirannya, melainkan sesuatu yang diperoleh dari luar. Sebagaimana aspekaspek kepribadian yang diperlihatkan seseorang sebagian adalah hasil pengaruh-pengaruh dan rangsangan-rangsangan dari luar, demikian pula halnya dengan tingkah-laku yang bermoral.

\section{Nilai-Nilai Moral}

Don S. Otis mengatakan bahwa, ketika kita bicara mengenai membesarkan anak bermoral, pertama-tama, adalah penting untuk memutuskan nilai-nilai siapa yang kita inginkan agar mereka ikuti. $^{35}$ Selanjutnya ia berkata bahwa bagi orang Kristen yang percaya kepada Alkitab, ini bukanlah teka-teki. Namun, bagi kaum sekuler, hal ini tidaklah terlalu jelas. ${ }^{36}$ Hal pertama yang perlu diketahui oleh orang tua dalam menanamkan nilai-nilai moral bagi anak adalah menentukan nilai-nilai moral yang

35 Don S. Otis, Membina Anak Bermoral (Bandung: Yayasan Kalam Hidup, 2003), 25.

${ }^{36}$ Ibid,. 25. 
berdasarkan pada prinsip Firman Tuhan. Orang tua harus memahami apa yang dikatakan oleh firman Allah sebelum mereka mengajarkan nilai-nilai alkitabiah kepada anak-anak mereka. Orang tua pun harus menaati dan mengikuti nilai-nilai alkitabiah dalam setiap keputuan yang dibuat.

\section{Kejujuran}

Kejujuran merupakan salah satu dari nilai-nilai inti, yaitu bahan baku sejati yang dapat membentuk integritas dan kematangan pribadi. $^{37}$ Sebagai orang tua tugas kita ialah membimbing anak-anak kita agar mempunyai hati nurani yang jernih, mempunyai komitmen untuk berlaku jujur, dan sanggup untuk berpikir sendiri. ${ }^{38}$

Kejujuran meruapakan standar moral yang baik. Mengajari anak-anak berlaku jujur sungguh sebuah tantangan, sebab di dunia nyata sekitar mereka banyak contoh tentang ketidakjujuran. Teladan orang tua, dan kebiasaan menanggapi perilaku anak, dapat memberi pengaruh yang kuat pada anak. ${ }^{39}$

\section{Kemurnian dan Kesucian}

37 Paul Lewis, Cara Mengarahkan Anak-Anak (Bandung: Kalam Hidup, 1997), 153.

${ }^{38}$ Ibid,. 154.

39 Linda \& Richard Eyre, Mengajarkan Nilai-Nilai Kepada Anak (Jakarta: Gramedia Pustaka Utama, 1999), 4.
Kesadaran untuk menjaga nilai kesucian sebelum dan sesudah perkawinan. Memahami tujuan perkawinan dan peran seksualitas di dalamnya. Kesadaran tentang akibat jangaka panjang (dan meluas) yang dapat ditimbulkan oleh kehidupan seksual yang tidak bermoral. ${ }^{40}$ Penyimpangan terhadap seksualitas bisa terjadi pada remaja yang tdak memiliki konsep tentang kermurnian dan kesucian hidup. Hal ini bisa terjadi karena orang tua tidak pernah membicarakan masalah seksualitas kepada anak, sehingga ada kecenderungan bagi anak untuk mencari informasi dari pihak lain, bahkan anak mencoba untuk melakukanya. Sebagai upaya penaggulanggan yang harus dilakukan oleh orang tua adalah dengan memberikan pengetahuan tentang seks seusia dini.

Sebagai orang tua Kristen seharusnya sudah mengetahui prinsip alkitab tentang kesucian hidup, sehingga orang tua tentunya mempunyai tanggung jawab dalam mengarahkan anak-anak mereka untuk memiliki nilai kesuciaan hidup dalam diri mereka.

\section{Setia dan Dapat Dipercaya}

Setia kepada kelaurga, kepada pekerjaan, kepada Negara, kepada sekolah, kepada organisasi serta lembaga lain kepada siap kita bertanggung jawab. Siap mendukung, siap melayani, siap

${ }^{40}$ Ibid,. 80. 
membantu. Dapat dipercaya dan konsisten dalam melaksanakan janji. ${ }^{41}$ Setia dan dan dipercaya adalah bagian dari nilai-nilai moral yang harus dimiliki oleh semua manusia.

\section{Kemerosotan Moral Anak/Remaja}

Thomas Lickona, seorang ahli psikologi perkembangan, menyebutkan sepuluh tren kepribadian anak-anak muda zaman sekarang yang sangat menyulitkan, yaitu: meningkatnya kejahatan kaum muda; meningkatnya ketidakjujuran (membohong, menipu, mencuri); sikap semakin tidak hormat terhadap para orang tua, guru, dan orang lain yang memiliki otoritas; meningkatnya kekejaman diantara rekan sebaya; merosotnya gaya bicara yang sopan; merosotnya etika kerja; merosotnya rasa tanggung jawab kepada masyarakat dan kepada diri sendiri; melonjaknya perilaku merusak diri seperti kegiatankegiatan seks yang terlalu dini, penyalahgunaan alkohol, dan narkoba, dan bunuh diri; meningkatnya ketidakpahaman akan etika, termasuk ketidakpedulian terhadap pengetahuan moral sebagai dasar dari kaidah kencana (Matius 7:12) dan kecenderungan untuk terlibatdalam perilaku merusak diri

${ }^{41}$ Ibi,. 101.
tanpaMenganggapnya

suatu kesalahan. ${ }^{42}$

Moral remaja dari tahun ketahun terus mengalami penurunan kualitas atau degradasi. Dalam segala aspek moral, mulai dari tutur kata, cara berpakaian dan lain-lain. Degradasi moral ini seakan luput dari pengamatan dan dibiarkan terus berkembang. Dunia narkoba dan seks bebas akhir-akhir ini memang sangat ngetren di kalangan remaja. Ini tandanya ada bukti lagi bahwa moral remaja masa kini memang sudah menurun. Kebudayaan timurnya sudah termakan oleh westernisasi jaman. Sangat memprihatinkan.

\section{Faktor Penyebab Kemerosotan Moral Anak/Remaja}

Faktor utama yang mengakibatkan degradasi moral remaja ialah perkembangan globalisasi yang tidak seimbang. Virus globalisasi terus menggerogoti bangsa ini. Sayangnya kita seakan tidak sadar, namun malah mengikutinya. Kita terus menuntut kemajuan di era global ini tanpa memandang (lagi) aspek kesantunan budaya negeri ini. Ketidak seimbangan itulah yang pada akhirnya membuat moral semakin jatuh dan rusak. Demikian pula masih banyak

42 Don S. Otis, Membina Anak bermoral: Menolong Anak-Anak membuat Pilihan Moral (Bandung: Kalam Hidup, 2003), 14. 
faktor yang dapat menjadi penyebab dari terjadinya kemerosotan moral pada remaja, selain perkembangan globalisasi beberap faktor yang bisa kita jumpai adalah:

\section{Kurangnya perhatian dan} pendidikan agama oleh keluarga

Orang tua adalah tokoh percontohan oleh anak-anak termasuk didalam aspek kehidupan sehari-hari tetapi didalam soal keagamaan hal itu seakan-akan terabaikan. Sehingga akan lahir generasi baru yang bertindak tidak sesuai ajaran agama dan bersikap materialistik.

Anak yang tidak mendapat ajaran dari orang tua, mudah untuk melakukan penyimpangan terhadap nilai-nilai moral. Kurangnya perhatian yang serius dari orang tua untuk memberikan bimbingan kepada anak yang sedang mengalami masalah, bisa juga disebabkan oleh kurangnya pemahaman terhadap diri sendiri sebagai seorang yang perlu memberikan bantuan kepada anak yang menghadapi masalah.

Banyak orang tua yang tidak memberikan bantuan berupa bimbingan kepada anak yang sedang mengalami masalah, selanjutnya banyak orang tua yang tidak mengadakan ibadah keluarga hal ini diakibatkan oleh kurangnya pemahaman orang tua terhadap penting ibadah keluarga. Kerapuhan inilah yang dapat menjadi pemicu dimana anak akan mengalami perkembangan dan pertumbuhan moral yang bermasalah.

\section{Pengaruh lingkungan yang tidak baik}

Kebanyakan remaja yang tinggal di kota besar menjalankan kehidupan yang individualistik dan materialistik. Sehingga kadang kala didalam mengejar kemewahan tersebut mereka sanggup berbuat apa saja tanpa menghiraukan hal itu bertentangan dengan agama atau tidak, baik atau buruk.

Lingkungan merupakan tempat anak bertumbuh dan berkembang, baik lingkungan keluarga, lingkungan sekolah dan lingkungan bermain. Lingkungan menjadi salah satu faktor yang dapat membentuk moral anak, sehingga baik buruknya moral anak dapat ditentukan oleh lingkungan dimana anak sedang bertumbuh dan berkembang. Tidak dapat dipungkiri bahwa lingkungan yang tidak baik merupakan suatu fakta yang ada di tengah-tengah kehidupan para remaja. Para remaja selalu diperhadapkan dengan pengaruhpengaruh dari lingkungan dimana remaja sedang bertumbuh dan berkembang, pengaruh dapat bersifat positif, tetapi bias pula bersifat negatif, hal ini tergantung pada lingkungan mana dimana anak sedang berada. Jika para remaja sedang bertumbuh dan 
berkembang dalam lingkungan yang tidak baik, maka akan terdapat kemungkinan dimana para remaja akan memiliki moral yang tidak baik, tetapi jika para remaja bertumbuh dan berkembang di tengah-tengah lingkungan yang baik, maka dampak yang dapat dihasilkan adalah para remaja memiliki moral yang baik.

Lingkungan yang tidak baik dapat berdampak buruk terhadap perkembangan dan pertumbuhan moral anak. Anak yang tadinya tidak memiliki kebiasaan merokok dan minum minuman keras dapat memiliki kebiasaan merokok dan minum minuman keras karena bergaul dalam lingkungan yang terbiasa dengan hal-hal demikian. Anak yang bertumbuh dalam lingkungan yang memiliki kecenderungan untuk melakukan kekerasan terhadap orang lain, lambat laun kebiasan tersebut akan menjadi sebuah kebiasaannya. Sehingga akan selalu ada kemungkinan dimana prilaku kekerasan di tiru dan dipraktekan. Dengan demikian lingkungan sangat menentukan sebuah pembentukan moral anak.

\section{Tekanan psikologi yang dialami} Anak

Tekanan psikologi menjadi salah satu faktor yang dapat menyebabkan kemerosotan moral anak. Anak yang sering dimarahi ataupun dipukuli oleh orang tua akan melarikan diri kepada hal-hal yang dapat merusak dirinya. Anak yang suka dimarahi dan dipukul oleh orang tuanya sering lari kepada mengkonsumsi minuman keras, tentunya dengan tujuan adalah mendapatkan ketenangan. Anak yang suka dimarahi dan dipukuli oleh orang tua biasanya akan menjadi anak yang tidak lagi menaruh hormat kepada orang tua, anak akan menjadi musuh bagi orang tua. Pada saat anak tidak lagi menaruh hormat kepada orang tua, maka ini merupakan sebuah awal dimana anak tidak lagi mau diatur. Anak tidak akan memperhatikan nasehat dari orang tua.

Tekanan-tekanan psikologi yang dialami oleh anak tanpa adamya sebuah upaya untuk menyelesaikannya akan berdampak buruk pada prilaku anak, misalnya: anak yang sering dipukuli oleh orang tuanya akan berdampak buruk pada prilaku anak yang dapat saja meniru perbutan orang tuanya atau anak akan lari kepada hal-hal yang bersifat negatif, misalnya anak yang sering dipukul akan lari kepada minuman-minuman keras. Perlakuan orang tua yang terlalu kasar terhadap anak dapat berpengaruh pada pertumbuhan dan perkembangan moral anak.

Beberapa remaja mengalami tekanan psikologi ketika di rumah diakibatkan adanya perceraian atau pertengkaran orang tua yang menyebabkan si anak tidak betah di rumah dan menyebabkan dia 
mencari

pelampiasan.

pun bisa menghasilkan dampak Pertengkaran yang sering terjadi antara orang tua juga dapat menjadi contoh yang tidak baik bagi pertumbuhan dan perkembangan anak. Anak yang sering kali melihat orang tuanya bertengkar dapat berdampak pula pada waktu ia berkeluarga di kemudian hari.

\section{Perkembangan teknologi modern}

Dengan perkembangan teknologi modern saat ini seperti mengakses informasi dengan cepat, mudah dan tanpa batas juga memudahkan remaja untuk mendapatkan hiburan yang tidak sesuai dengan mereka.

Dewasa ini perkembangan teknologi modern berkembang dengan begitu pesat, teknologi modern memberikan kemudahankemudahan kepada manusia, namun di sisi lain perkembangan teknologi menjadi momok bagi para orang tua terhadap anakanaknya. Orang tua menjadi miris dengan adanya kemajuan teknologi, karena hal ini bisa menimbulkan dampak yang negatif terhadap anak. Penyalagunaan teknologi modern oleh kalangan remaja dapat berdampak pada merosotnya moral mereka.

Perkembangan teknologi modern dan media masa merupakan suatu kemajuan yang saat ini sedang dialami oleh manusia. Di satu sisi hal ini sangat memiliki dampak yang positif bagi manusia, namun di sisi lain hal ini

yang negatif. Perkembangan teknologi modern dan media masa juga sudah dinikmati oleh para remaja. Kurangnya pengawasan yang diberikan oleh orang tua kepada para remaja, memberikan peluang bagi mereka untuk menggunakan teknologi modern untuk hal-hal yang tidak bermoral. Anak akan menjadi korban teknologi bilamana orang tua tidak memberikan pengawasan terhadap tontonan-tontonan yang dilihat oleh anak di televisi. Karena sebagian besar sajian-sajian yang ditawarkan oleh dunia perfilman adalah film-film yang beradegan kekerasan dan juga berbau pornografi. Anak yang terindikasi telah mengalami kemerosotan moral akibat faktor teknologi modern dapat disebabkan oleh kurangnya pendidikan yang diberikan oleh orang tua. Orang tua tidak mendidik bahwa menonton film-film yang beradegan kekerasan dapat membentuk karakter anak menjadi anak yang dapat juga berlaku kekerasan. Banyak anak yang menonton film-film beradengan seks dapat pula disebabkan oleh kurangnya didikan yang diberikan oleh orang tua, berupa laranganlarangan untuk tidak menonton film-film yang beradegan seks.

\section{KESIMPULAN}

Degradasi atau kemerosotan moral merupakan 
sebuah kenyataan yang terjadi dalam sejarah kehidupan manusia. Kemerosotan moral melingkupi seluruh lapisan masyarakat, termasuk di dalamnya adalah para remaja. Tentunya kemerosotan moral ini disebabkan oleh banyak faktor, antara lain: Pertama, Kurangnya perhatian dan pendidikan agama yang diberikan oleh orang tua kepada anak. Kedua, Pengaruh lingkungan yang tidak baik. Ketiga, Tekanan psikologi yang dialami oleh anak. Keempat, Pengaruh teknologi modern. Tidak dapat dipungkiri bahwa teknologi modern menjadi sajian yang dapat memberikan dampak yang positif, namun disisi lain dapat juga memberikan dampak yang negatif. Para remaja yang memiliki spiritual yang rapuh, dapat dengan gampang menggunkan tekonologi modern untuk hal-hal yang negatif. Misalnya: menggunakan internet untuk mengakses gambar dan video porno.

\section{KEPUSTAKAAN}

Alkitab, Kamus dan Buku-buku Lembaga Alkitab Indonesia. Jakarta: 2006

Kamus Besar Bahasa Indonesia. (Jakarta: Balai Pustaka, 2001

Arterburn, Stephen dan Burns, Jim Arahkan dengan Jitu: Kiat Menanamkan Nilai-Nilai Kekristenan pada Remaja. Yogyakarta: ANDI, 2010.
Backus, Candera \& William. Menjadi Orang Tua Yang Berwibawah. Jakarta: YPII, 1995.

Dyrness, William. Tema-Tema Dalam Teologi Perjanjian Lama. Malang: Gandum Mas, 1979.

Gunarsa, Y. Singgih D. Psikologi Perkembangan Anak dan Remaja. Jakarta: BPK Gunung Mulia, 2008.

Graham, Billy. Keluarga Yang Berpusatkan Kristus. Bandung: Kalam Hidup, 1997.

Heath, W. Stanley. Teologi Pendidikan: Dasar Pelayanan Kepada Anak. Bandung: Kalam Hidup, 2005.

Linda \& Eyre, Richard. Mengajarkan Nilai-Nilai Kepada Anak. Jakarta: Gramedia Pustaka Utama, 1999.

Lessin, Roy. Disiplin Keluarga. Malang: Gandum Mas, 1978.

Lewis Paul, Cara Mengarahkan Anak-Anak. Bandung: Kalam Hidup, 1997

Mayeroff, Milton.

Seni

Memperhatikan.

Gramedia Pustaka Kita, 1991.

Otis, S. Don. Membina Anaka Bermoral: menolong AbakAnak membuat Pilihan Moral. Bandung: Kalam Hidup, 2003

Riemer, G. Ajarlah Mereka. Jakarta: Yayasan 
Komunikasi Bina

Kasih/OMF, 2006.

Santrock, W. John. Adolescence.

Perkembangan Remaja. Jakarta:

Erlangga, 1997.

Schuller, Robert A. Mencari Nilai-

Nilai Moral. Batam: Gospel Press, 2005.

Shochib, Moh. Pola Asuh Orang Tua: Dalam Membantu Anak

Mengembangkan Disiplin

Diri (Jakarta: PT. Rineka Cipta, 1998)

Sidjabat, B. S. Strategi Pendidikan

Kristen: Suatu Tinjauan

Teologis-Filosofis

(Yogyakarta: Yayasan ANDI, 1999)

Wijanarko, Jarot. Anak Berakhlak:

Kecerdasan Spiritual.

Tangerang: PT. Happy Holy

Kids.2007

Mendidik Anak:

Nilai Hidup, Integritas, dan

Karakter. Jakarta: Suara

Pemulihan, 2008.

Wolterstorf, Nicholas P. Mendidik

Untuk Kehidupan: Refleksi

Mengenai Pengajaran dan

Pembelajaran Kristen.

Surabaya: Momentum, 2007 